УДК 346:338.49-021.131

DOI https://doi.org/10.32849/2663-5313/2021.2.08

\title{
Юрій Георгієвсъкий,
}

докт. юрид. наук, доиент,

завідувач наукового відділу правового забезпечення галузевого інновачійного розвитку

Науково-дослідного інституту правового забезпечення інновачійного розвитку

Національної академії правових наук Украӥни,

дочент кафедри адміністративного права

Наиіонального юридичного університету імені Ярослава Мудрого

\section{ЗАКОНОДАВЧЕ РЕГУЛЮВАННЯ ПРІОРИТЕТНИХ НАПРЯМІВ ІННОВАЦІЙНОЇ ДІЯЛЬНОСТІ В УКРАЇНІ}

Робота присвячена визначенню актуальних проблем законодавчого регулювання пріоритетних напрямів інновачійної діяльності в Україні та розробиі пропозииій щодо їх вирішення. Спираючись на системний аналіз положень законів України «Про пріоритетні напрями інноваційної діяльності в Україні», «Про пріоритетні напрями розвитку науки і техніки», «Про державні цільові програми», а також інших нормативних актів у хронологічній перспективі, автор констатує наявність множинних проблем, що стосуються як змісту законодавчих норм, так і належного їх виконання у сфері правового регулювання планування інновачійної діяльності в Україні. Актуальними проблемами законодавчого регулювання пріоритетних напрямів інновачійної діяльності в роботі визначено: ускладнений та перевантажений механізм законодавчого визначення стратегічних та середньострокових напрямів інноваиійної діяльності; порушення прочедури та строків формування пріоритетних напрямів інноващійної діяльності в Україні на період після 2021 року; неналежне дотримання вимог закону відповідальними за ией напрям діяльності міністерствами; невідповідність змісту Порядку формування, експертизи та обговорення пріоритетних напрямів інновачійної діяльності положенням Закону України «Про пріоритетні напрями інноваиійної діяльності в Україні»; відсутність чинної Методики проведення експертизи стратегічних пріоритетних напрямів інновачійної діяльності та середньострокових пріоритетних напрямів інноваційної діяльності загальнодержавного рівня. У статті підсумовано, що відсутність чинної методики експертизи та застарілий порядок формування зазначених напрямів актуалізують ризики визначення недочільних стратегічних пріоритетних напрямів інновачійної діяльності, далеких від актуальних світових інновачійних трендів. Автором запропоновано такі актуальні напрями подолання виявлених проблем: перегляд правового механізму визначення пріоритетних напрямів у бік спрощення процедур розгляду та узгодження; приведення у відповідність змісту законодавчих актів, що регулюють визначення пріоритетних напрямів інновачійної діяльності, та оперативної розробки відповідної державної иільової програми.

Ключові слова: планування інноваційної діяльності, національна інноваційна система, інноваційний розвиток, орган публічної влади, експертиза, прогалини правового регулювання, державна цільова програма.

Постановка проблеми. Аналіз останніх досліджень і публікацій. Розвиток національної інноваційної системи ${ }^{1} є$ беззаперечним пріоритетом державної політики сучасних країн в умовах розбудови інноваційних економік та світової технологічної конкуренції. Саме такий критерій є ключовим у форму-

${ }^{1}$ Тут і далі під національною інноваційною системою ми розуміємо «сукупність законодавчих, структурних і функціональних компонентів (інституцій), які задіяні у процесі створення та застосування наукових знань та технологій і визначають правові, економічні, організаційні та соціальні умови для забезпечення інноваційного процесу» [1]. ванні світових рейтингів конкурентоспроможності [2], тому законодавче регулювання планування інноваційної діяльності має бути сучасним, досконалим та мобільним, відповідаючи динамічній природі інновацій. Українські дослідники національної інноваційної системи І.В. Багрова та О.Л. Черевко відзначають наявність прямої залежності недоліків інноваційного розвитку України від рівня ефективності управління на рівні держави [3]

Разом із тим сучасні вітчизняні науковці все частіше звертають увагу на необхідність удосконалення національного законодавства, що регулює здійснення інноваційної діяльності в Україні. Приміром, А.І. Яковлев, 
аналізуючи шляхи поліпшення стану інноваційної діяльності в Україні, виокремлює наявність низки проблем у законодавчій сфері Перепонами, що гальмують інноваційний розвиток в Україні, дослідник вважає відсутність податкового стимулювання інноваційноінвестиційної діяльності, системи пільгового кредитування розробників та розповсюджувачів інновацій, недостатнє державне страхування і гарантії інвесторам [4]. Поділяючи позиції дослідника, зазначимо, що наведений перелік проблем більшою мірою визначає перспективу запровадження наведених напрямів на законодавчому рівні. Водночас не менш нагальним є здійснення системного аналізу чинного українського законодавства $з$ метою виявлення наявних прогалин та колізій у правовому регулюванні розвитку національної інноваційної системи.

Дослідниця Г.В. Сршова за результатами вивчення тенденцій та проблем здійснення інноваційної діяльності в Україні наголошує на необхідності чіткого визначення державних пріоритетів інноваційної діяльності в Україні та розроблення всебічного комплексу заходів щодо їхнього сприяння з метою розбудови інноваційної економіки [5]. Такий акцент дослідниці, на наше переконання, не $€$ випадковим, оскільки визначення правових, економічних та організаційних засад формування цілісної системи пріоритетних напрямів інноваційної діяльності було покладено законодавцем у визначення мети Закону України «Про пріоритетні напрями інноваційної діяльності в Україні» [6]. Цей закон має особливе значення для активізації інноваційної діяльності та розвитку національної інноваційної системи, оскільки він передбачає заходи реалізації державою пріоритетних напрямів інноваційної діяльності, серед яких присутні механізми прямого бюджетного фінансування, кредитів за рахунок коштів державного бюджету, субвенцій, відшкодування відсоткових ставок за кредитами тощо.

Формування цілей статті. Метою даної наукової розвідки $є$ визначення актуальних проблем законодавчого регулювання пріоритетних напрямів інноваційної діяльності в Україні та пошук шляхів їх вирішення.

Виклад основного матеріалу. Метою Закону України «Про пріоритетні напрями інноваційної діяльності в Україні» [6] $є$ забезпечення інноваційної моделі розвитку економіки шляхом концентрації ресурсів держави на пріоритетних напрямах науковотехнічного оновлення виробництва, підвищення конкурентоспроможності вітчизняної продукції на внутрішньому і зовнішньому ринках. Тому забезпечення безперервного законодавчого регулювання зазначеної сфери правовідносин є вкрай актуальним, що зумовлює потребу в дослідженні відповідних механізмів правового регулювання і стану їх реалізації.

Ст. 4 Закону України визначає 7 стратегічних пріоритетних напрямів інноваційної діяльності в Україні на 2011-2021 роки: 1) освоєння нових технологій транспортування енергії, впровадження енергоефективних, ресурсозберігаючих технологій, освоєння альтернативних джерел енергії; 2) освоєння нових технологій високотехнологічного розвитку транспортної системи, ракетно-космічної галузі, авіа- і суднобудування, озброєння та військової техніки; 3) освоєння нових технологій виробництва матеріалів, їх оброблення і з'єднання, створення індустрії наноматеріалів та нанотехнологій; 4) технологічне оновлення та розвиток агропромислового комплексу; 5) впровадження нових технологій та обладнання для якісного медичного обслуговування, лікування, фармацевтики; 6) широке застосування технологій більш чистого виробництва та охорони навколишнього природного середовища; 7) розвиток сучасних інформаційних, комунікаційних технологій, робототехніки. При цьому очевидним $є$ те, що поточний рік є останнім роком дії зазначених стратегічних пріоритетних напрямів [6].

Законодавцем запроваджено два різновиди пріоритетних напрямів інноваційної діяльності в Україні, що мають діалектичний зв'язок. Відповідно до ст. 2 Закону пріоритетні напрями інноваційної діяльності в Україні поділено на стратегічні, тобто ті, що визначаються на період до 10 років, і середньострокові, тобто ті, які визначаються на період до 5 років. При цьому середньострокові пріоритетні напрями визначаються 3 метою поетапного забезпечення реалізації стратегічних пріоритетних напрямів на загальнодержавному, галузевому i регіональному рівнях, тобто мають їм відповідати [6]. У разі належного законодавчого регулювання такий взаємозв'язок стратегічних та середньострокових пріоритетних напрямів сприяє синергетичному розвитку національної інноваційної системи. Водночас прогалини законодавчого регулювання стратегічних пріоритетних напрямів, відповідно, створюють суттєві перешкоди або взагалі унеможливлюють належне визначення і виконання середньострокових пріоритетних напрямів на усіх рівнях. Усі пріоритетні напрями інноваційної діяльності має бути визначено відповідно до Закону, тобто 
сформовано та затверджено відповідно до встановленого законодавством порядку.

Чинний механізм законодавчого регулювання формування та визначення пріоритетних напрямів інноваційної діяльності передбачає послідовні дії уповноважених органів публічної влади. Йдеться, зокрема, про розроблення пропозицій (із залученням наукової громадськості), їх схвалення у вигляді проектів нормативних актів та затвердження цих актів органами публічної влади у межах компетенції у встановлені строки.

Системний аналіз положень Закону України «Про пріоритетні напрями інноваційної діяльності в Україні» дозволяє дійти висновку про надскладний та бюрократично перевантажений механізм законодавчого визначення цих напрямів, що передбачає багато етапів підготовки та ступенів узгодження. Проілюструємо деякі аспекти, що актуалізують такий висновок. Відповідно до ч. 2 ст. 3 Закону підготовка пропозицій щодо стратегічних пріоритетних напрямів та їх прогнозно-аналітичне обгрунтування мають здійснюватися із залученням Національної академії наук України, національних галузевих академій наук України, вищих навчальних закладів і науководослідних інститутів у рамках державних цільових програм прогнозування науковотехнічного та інноваційного розвитку України відповідно до законів України «Про пріоритетні напрями розвитку науки і техніки» [7] та «Про державні цільові програми» [8]. У ст. 4 Закону України «Про пріоритетні напрями розвитку науки і техніки» зазначається, що таку державну цільову програму Уряд розробляє і здійснює на підставі рекомендацій Національної ради України 3 питань розвитку науки і технологій із залученням Національної академії наук України, національних галузевих академій наук, центральних органів виконавчої влади відповідно до Закону України «Про державні цільові програми» [7].

Отже, зважаючи на приписи ст. 3 Закону України «Про пріоритетні напрями інноваційної діяльності в Україні» та відповідно до ст. 4 Закону України «Про пріоритетні напрями розвитку науки і техніки», можна дійти висновку, що Уряд до кожного зі стратегічних пріоритетних напрямів інноваційної діяльності має подавати до Парламенту: 1) обгрунтування необхідності прийняття пріоритетного напряму, очікувані результати та їх вплив на економіку України; 2) оцінку науково-технічного потенціалу та наукових шкіл, які будуть задіяні в реалізації пріоритетного напряму, оцінку існуючих об'єктів права інтелектуальної власності та наукових результатів, що будуть покладені в основу реалізації пріоритетного напряму; 3) пропозиції до пріоритетних тематичних напрямів наукових досліджень і науково-технічних розробок, визначення фахівців та базових наукових установ, що мають здійснювати науково-технічний супровід пріоритетного напряму; 4) концепцію реалізації пріоритетного напряму та оцінку фінансових, матеріально-технічних ресурсів, які мають бути залучені для його реалізації [6]. 3 одного боку, такий порядок розробки пріоритетних напрямів інноваційної діяльності сприяе системному опрацюванню відповідних пропозицій, а з іншого - формує умови для хронологічної пролонгації та бюрократичного ускладнення цього процесу.

Наведений ускладнений правовий механізм визначення пріоритетних напрямів інноваційної діяльності, на наше переконання, став чинником появи інших проблем законодавчого регулювання цієї сфери. Зокрема, він зумовив порушення процедури та строків формування пріоритетних напрямів інноваційної діяльності на період після 2021 року.

У цьому зв'язку варто звернути увагу на те, що пропозиції щодо стратегічних пріоритетних напрямів та їх прогнозно-аналітичне обгрунтування згідно зі ст. 3 Закону має готувати центральний орган виконавчої влади, що реалізує державну політику у сфері науково-технічної та інноваційної діяльності (Міністерство освіти та науки України відповідно до Положення [9]) із залученням Національної академії наук України, національних галузевих академій наук України, вищих навчальних закладів і науково-дослідних інститутів. Це міністерство має подати їх на розгляд центрального органу виконавчої влади, що забезпечує формування державної політики у сфері інновацій (Міністерство розвитку економіки, торгівлі та сільського господарства України відповідно до Положення [10]), що має внести їх на розгляд Кабінету Міністрів України. КМУ має схвалити обгрунтовані Мінекономіки пропозиції стратегічних пріоритетних напрямів та подати їх у вигляді проектів законів до Верховної Ради України до 1 березня передостаннього року дії попередніх стратегічних пріоритетних напрямів (тобто до 01 березня 2020 року). Отже, Парламент мав би затвердити стратегічні пріоритетні напрями інноваційної діяльності на 2022-2031 роки (тобто на наступний десятирічний період) шляхом внесення змін до ст. 4 профільного закону до 01 березня 2020 року (оскільки вона встановлюе стратегічні пріоритетні напрями інноваційної діяльності на 2011-2021 роки), 
чого здійснено не було. У цьому ми вбачаємо другу актуальну проблему законодавчого регулювання пріоритетних напрямів інноваційної діяльності в Україні, а саме фактичне порушення законодавчого порядку формування стратегічних напрямів на наступний довгостроковий період.

Наступна проблема законодавчого регулювання пріоритетних напрямів інноваційно діяльності полягає у поточній відсутності в Україні державної цільової програми, яка б визначала найбільш перспективні напрями, варіанти та заходи розвитку науково-технологічної та інновачійної діяльності в Украйні. Це, у свою чергу, унеможливлює отримання бюджетного фінансування на розвиток відповідних пріоритетних напрямів завдяки застосуванню програмного методу. І хоча нещодавно Урядом була затверджена Державна програма стимулювання економіки для подолання негативних наслідків, спричинених обмежувальними заходами щодо запобігання виникненню і поширенню гострої респіраторної хвороби COVID-19 на 2020-2022 роки [11], в якій міститься тематичний розділ щодо підтримки інновацій, ми наголошуємо на необхідності ухвалення самостійної програми, що б визначала пріоритетні напрями науково-технологічної та інноваційної діяльності в Україні. Останньою державною цільовою програмою в цьому напрямі була Державна програма прогнозування науково-технологічного розвитку на 2008-2012 роки [12]. Водночас згодом Уряд постановою від 22 червня 2011 р. № 704 «Про скорочення кількості та укрупнення державних цільових програм» [13] визнав такою, що втратила чинність, зазначену Постанову «Про затвердження Державної програми прогнозування науково-технологічного розвитку на 2008-2012 роки» (пункт 23 переліку), у зв'язку з чим ії так і не було повноцінно реалізовано. Ця проблема, на нашу думку, потребує правового вирішення. Зокрема, йдеться про необхідність оперативного розроблення МОН і затвердження Урядом Державної цільової програми прогнозування науковотехнологічного та інноваційного розвитку України на 2021-2030 роки, що сприятиме формуванню фінансових можливостей для розвитку національної інноваційної системи України.

Окремої уваги потребує аналіз формування середньострокових пріоритетних напрямів загальнодержавного і галузевого рівнів. Як вже зазначалося, вони формуються на основі визначених Законом стратегічних пріоритетних напрямів 3 метою поетапного забезпечення їх реалізації. Фактично середньострокові пріоритетні напрями є найбільш динамічними та мобільними за своєю природою, оскільки мають оперативно адаптувати державну політику до нових світових інноваційних трендів.

Відповідно до ст. 5 Закону середньострокові пріоритетні напрями загальнодержавного і галузевого рівнів має затверджувати КМУ за поданням Міністерства розвитку економіки, торгівлі та сільського господарства України протягом трьох місяців 3 дня визначення законом стратегічних пріоритетних напрямів інноваційної діяльності. Далі механізм формування є відмінним для напрямів загальнодержавного і галузевого рівнів. Пропозиції для Мінекономіки щодо середньострокових пріоритетних напрямів загальнодержавного рівня має формувати Міністерство освіти і науки України із залученням наукової громадськості, пропозиції щодо середньострокових пріоритетних напрямів галузевого рівня - відповідні центральні органи виконавчої влади, що відповідають за окремі галузі економіки. У свою чергу, середньострокові пріоритетні напрями регіонального рівня має затверджувати Верховна Рада Автономної Республіки Крим за поданням Ради міністрів Автономної Республіки Крим та місцеві ради за поданням місцевих державних адміністрацій. При цьому пропозиції щодо середньострокових пріоритетних напрямів мають спиратися на сформовані та затверджені пріоритетні напрями вищого рівня та враховувати результати прогнозно-аналітичних досліджень економічного і соціального розвитку відповідного рівня - держави в цілому, окремих галузей економіки та окремого регіону [6]. Як бачимо, механізм формування та затвердження $є$ багатоступеневим та передбачає декілька рівнів, що суперечить динамічній природі цих напрямів, які мають оперативно переорієнтувати розвиток національної інноваційної системи залежно від зовнішніх викликів.

Недоліки формування середньострокових пріоритетних напрямів, визначені нами у теоретичній площині, мають багато практичних обгрунтувань. Так, приміром, на період 2017-2021 роки Уряд постановою від 28 грудня 2016 р. № 1056 [14] затвердив такі середньострокові пріоритетні напрями інноваційної діяльності загальнодержавного рівня у медичній сфері, як «впровадження нових технологій та обладнання для якісного медичного обслуговування, лікування, фармацевтики». Ці напрями було деталізовано постановою від 18 жовтня 2017 р. № 980 [15] середньостроковими пріоритетними напрямами галузевого рівня на аналогічний п’ятирічний період. При цьому, приміром, 
у відповідь на сучасний світовий виклик, що постав перед Україною у 2020 році через пандемію, до переліку затверджених середньострокових пріоритетних напрямів «впровадження нових технологій та обладнання для якісного медичного обслуговування, лікування і фармацевтики» Урядом не було внесено жодних змін. Безсумнівно, такі зміни мали би бути спрямовані на визнання державою актуальності й пріоритетності технологій розроблення методів діагностики, лікування та профілактики COVID-19. По-перше, такий стан є наслідком неналежного дотримання вимог закону відповідальними за цей напрям діяльності міністерствами - Міністерством охорони здоров'я, яке мало б сформувати відповідні пропозиції, та Міністерством економіки, яке мало б ці пропозиції подати до Уряду для подальшого затвердження. По-друге, наведена ситуація актуалізує перегляд правового механізму визначення середньострокових пріоритетних напрямів загальнодержавного і галузевого рівнів у бік спрощення процедур розгляду та узгодження.

Окремою проблемою законодавчого регулювання пріоритетних напрямів інноваційної діяльності є внутрішня неузгодженість нормативних актів, зокрема невідповідність змісту Порядку формування, експертизи та обговорення пріоритетних напрямів інноваційної діяльності [16] положенням Закону України «Про пріоритетні напрями інноваційної діяльності в Україні» [6]. Перша проблема полягає в тому, що зазначений Порядок був ухвалений на виконання попереднього Закону України «Про пріоритетні напрями інноваційної діяльності в Україні» від 16 січня 2003 року № 433-IV, що втратив чинність у зв'язку з прийняттям чинного Закону від 08.09.2011 року. Проте оновлений Порядок відповідно до вимоги ч. 3 ст. 3 Закону так і не було затверджено.

Друга проблема пов'язана з невідповідністю наявному у Порядку механізму визначення стратегічних та середньострокових пріоритетних напрямів інноваційної діяльності змісту Закону. Згідно 3 порядком ці напрями разом з техніко-економічним обгрунтуванням мають подаватися до МОН міністерствами, іншими центральними органами виконавчої влади, Національною та галузевими академіями наук до 1 жовтня передостаннього року дії попередніх стратегічних пріоритетних напрямів інноваційної діяльності (пункт 2 Порядку [16]). При цьому саме МОН узагальнюе ці пропозиції, формує перелік стратегічних пріоритетних напрямів інноваційної діяльності та перелік середньострокових пріоритетних напрямів інноваційної діяльності загальнодержавного рівня, організовує проведення ïx експертизи, забезпечує обговорення 3 науковою громадськістю, надсилає зазначені переліки пріоритетних напрямів інноваційної діяльності з техніко-економічним обгрунтуванням до КМУ. Уряд має внести їх до Верховної Ради України до 1 березня останнього року дії попередніх стратегічних пріоритетних напрямів інноваційної діяльності (пункт 3 Порядку [16]). Ця норма суперечить ст. 3, 5 чинного Закону України «Про пріоритетні напрями інноваційної діяльності» [6], адже ними встановлено, що МОН готує пропозищї щодо стратегічних та середньострокових пріоритетних напрямів загальнодержавного рівня та подає $\boldsymbol{i} \boldsymbol{x}$ на розгляд Мінекономіки. Це міністерство у встановленому порядку вносить їх для схвалення на розгляд КМУ. Схвалені пропозиції щодо стратегічних пріоритетних напрямів КМУ має вносити до ВРУ у вигляді проектів законів до 01 березня передостаннъого року дії попередніх стратегічних пріоритетних напрямів. Відповідно до закону Мінекономіки, а не МОН є уповноваженим органом, відповідальним за підготовку до розгляду Урядом переліків стратегічних та середньострокових пріоритетних напрямів інноваційної діяльності загальнодержавного рівня. Окрім цього, Уряд має схвалити і внести їх до Парламенту не до 01 березня останнього року дії попередніх пріоритетних напрямів, а до 01 березня передостаннього року їхньої дії.

Останній момент, на який варто звернути увагу, - це визначення переваг попереднього механізму правового регулювання пріоритетних напрямів інноваційної діяльності, формування якого ми пов'язуємо з дією Закону України «Про пріоритетні напрями інноваційної діяльності» від 16 січня 2003 року, Порядку, ухваленого на його виконання, та Методики проведення експертизи стратегічних пріоритетних напрямів інноваційної діяльності та середньострокових пріоритетних напрямів інноваційної діяльності загальнодержавного рівня [17]. Зауважимо, що відповідно до Методики метою експертизи пріоритетних напрямів інноваційної діяльності було дослідження, перевірка, аналіз та оцінка науково-технічного рівня сформованих або уточнених МОН стратегічних пріоритетних напрямів інноваційної діяльності та середньострокових пріоритетних напрямів інноваційної діяльності загальнодержавного рівня [17]. Фактично експертно-аналітична думка під час формування органом публічного управління пропозицій пріоритетних напрямів інноваційної 
діяльності позиціонувалась як визначальна, адже у разі прийняття негативного висновку для відповідних уповноважених органів встановлювалося строкове обмеження для повторного подання документів на експертизу. Для МОН щодо стратегічних пріоритетних напрямів інноваційної діяльності тривалість строкового обмеження становила десять років. Для центральних органів виконавчої влади, виконавчих органів місцевого самоврядування, Національної та галузевих академій наук, громадських наукових та науково-технічних організацій щодо середньострокових пріоритетних напрямів інноваційної діяльності загальнодержавного рівня - три роки після відповідного негативного висновку (п. 8 [17]). На наше переконання, таке санкціонування сприяло формуванню більш відповідального підходу органів публічної влади до розроблення та належного обгрунтування пріоритетних напрямів інноваційної діяльності порівняно з поточним станом справ у цій галузі. Зазначимо, що дана методика втратила чинність у 2017 році у зв'язку з втратою чинності наказом від 19.12.2017 № 1631/1834/677/1033/754.

\section{Висновки}

Проведений аналіз законодавства, що регулює визначення пріоритетних напрямів інноваційної діяльності, засвідчив наявність множинних проблем, що стосуються як змісту законодавчих норм, так і належного їх виконання. У цьому зв’язку варто відзначити ускладнений та перевантажений механізм законодавчого визначення стратегічних та середньострокових напрямів інноваційної діяльності; виявлене порушення процедури та строків формування пріоритетних напрямів інноваційної діяльності в Україні на період після 2021 року; неналежне дотримання вимог закону відповідальними за цей напрям діяльності міністерствами; невідповідність змісту Порядку формування, експертизи та обговорення пріоритетних напрямів інноваційної діяльності положенням Закону України «Про пріоритетні напрями інноваційної діяльності в Україні»; відсутність чинної Методики проведення експертизи стратегічних пріоритетних напрямів інноваційної діяльності та середньострокових пріоритетних напрямів інноваційної діяльності загальнодержавного рівня тощо.

Варто наголосити, що за наявності виявлених розбіжностей та прогалин правового регулювання, які у сукупності створюють режим правової невизначеності, очевидними $€$ подальші ризики порушення встановленого законом строку формування та затвердження стратегічних пріоритетних напрямів іннова- ційної діяльності на наступний десятирічний період (2022-2031 років). У зв'язку з відсутністю чинної методики експертизи та застарілим порядком формування цих напрямів також актуалізуються i ризики визначення недоцільних стратегічних пріоритетних напрямів інноваційної діяльності, далеких від актуальних світових інноваційних трендів. Це, у свою чергу, може призвести до формування та реалізації безперспективних середньострокових пріоритетних напрямів у цій сфері та взагалі до гальмування розвитку національної інноваційної системи України. Ігнорування наведених ризиків, відсутність оперативного реагування і злагодженої взаємодії центральних органів виконавчої влади 3 науковою громадськістю, відповідальної роботи Уряду і Парламенту у стислі строки може призвести до нецільового витрачання коштів державного та місцевих бюджетів. Це, у свою чергу, створить перепони для інноваційного розвитку України, знизить її конкурентоспроможність у світі, спровокує появу нових кризових явищ у соціально-економічній сфері.

Актуальними напрямами подолання зазначених проблем є перегляд правового механізму визначення середньострокових пріоритетних напрямів загальнодержавного і галузевого рівнів у бік спрощення процедур розгляду та узгодження; приведення у відповідність змісту законодавчих актів, що регулюють визначення пріоритетних напрямів інноваційної діяльності, та оперативної розробки державної цільової програми, яка б визначала найбільш перспективні напрями, варіанти та заходи розвитку науково-технологічної та інноваційної діяльності в Україні.

\section{Список використаних джерел:}

1. Про схвалення Концепції розвитку національної інноваційної системи : Розпорядження Кабінету Міністрів України від 17 червня 2009 p. № 680-p. URL : https://zakon.rada.gov.ua/ laws/show/680-2009-\%D1\%80\#Text (дата звернення: 12.12.2020).

2. Про схвалення Стратегії розвитку сфери інноваційної діяльності на період до 2030 року : Постанова КМУ від 10 липня 2019 p. № 526-p. URL : https://zakon.rada.gov.ua/ laws/show/526-2019-\%D1\%80\#Text (дата звернення: 12.12.2020).

3. Багрова I.В., Черевко О.Л. Національна інноваційна система України: характеристика та проблеми становлення. Вісник ДДФА. 2010. № 2 (24). C. 81-90.

4. Яковлев А.І. Аналіз стану інноваційної діяльності в Україні та шляхи його поліпшення. Наука та наукознавство. 2018. № 2 (100). С. 29-44.

5. Єршова Г.В. Інноваційна діяльність в Україні: основні тенденції та проблеми. Економіка і прогнозування. 2017. № 4. С. 137-148. 
6. Про пріоритетні напрями інноваційної діяльності в Україні : Закон України від 8 вересня 2011 року № 3715-VI. Відомості Верховної Ради України. 2012. № 19-20. Ст. 166.

7. Про пріоритетні напрями розвитку науки і техніки в Україні : Закон України від 11 липня 2001 року № 2623-III. Відомості Верховної Ради України. 2001. № 48. Ст. 253.

8. Про державні цільові програми : Закон України від 18 березня 2004 року № 1621-IV. Вiдомості Верховної Ради України. 2004. № 2. Ст. 352.

9. Про затвердження Положення про Міністерство освітиінауки України:Постанова Кабінету Міністрів України від 16.10.2014 р. № 630. URL: http://zakon.rada.gov.ua/laws/show/630-2014\%D0\%BF (дата звернення: 01.01.2021).

10. Питання Міністерства розвитку економіки, торгівлі та сільського господарства : Постанова Кабінету Міністрів України від 11.09.2019 p. № 838. URL: https://zakon.rada.gov.ua/ laws/show/838-2019-\%D0\%BF (дата звернення: 29.12.2020).

11. Про затвердження Державної програми стимулювання економіки для подолання негативних наслідків, спричинених обмежувальними заходами щодо запобігання виникненню і поширенню гострої респіраторної хвороби COVID-19, спричиненої коронавірусом SARS-CoV-2, на 2020-2022 роки : Постанова КМУ від 27 травня 2020 p. № 534. URL: https://zakon.rada.gov.ua/ laws/show/534-2020-\%D0\%BF\#Text (дата звернення: 29.12.2020)

12. Державна програма прогнозування науково-технологічного розвитку на 2008-2012 роки : Постанова КМУ від 11 вересня
2007 p. № 1118. URL: https://zakon.rada.gov.ua/ laws/show/1118-2007-\%D0\%BF\#Text (дата звернення: 11.01.2021).

13. Про скорочення кількості та укрупнення державних цільових програм : Постанова КМУ від 22 червня 2011 р. № 704. URL: https:// zakon.rada.gov.ua/laws/show/704-2011-\%D0\%BF\# Text (дата звернення: 11.01.2021).

14. Деякі питання визначення середньострокових пріоритетних напрямів інноваційної діяльності загальнодержавного рівня на 2017-2021 роки : Постанова КМУ від 28 грудня 2016 p. № 1056. URL: https://zakon.rada.gov.ua/ laws/show/1056-2016-\%D0\%BF\#Text (дата звернення: 10.01.2021).

15. Деякі питання визначення середньострокових пріоритетних напрямів інноваційної діяльності галузевого рівня на 2017-2021 роки : Постанова КМУ від 18 жовтня 2017 р. № 980. URL: https://zakon.rada.gov.ua/laws/show/980-2017\%D0\%BF\#Text (дата звернення: 10.01.2021).

16. Про затвердження Порядку формування, експертизи та обговорення пріоритетних напрямів інноваційної діяльності : Постанова КМУ від 17 липня 2003 р. № 1094. URL: https:// zakon.rada.gov.ua/laws/show/1094-2003\%D0\%BF\#Text (дата звернення: 10.01.2021).

17. Про затвердження Методики проведення експертизи стратегічних пріоритетних напрямів інноваційної діяльності та середньострокових пріоритетних напрямів інноваційної діяльності загальнодержавного рівня : Наказ від 23.12.2003 № $840 / 382 / 528 / 459 / 688 / 513$. URL: https:// zakon.rada.gov.ua/laws/show/z0055-04\#Text (дата звернення: 10.01.2021).

Yurii Heorhiievskyi. Legislative regulation of priority areas of innovation activity in Ukraine

The article is dedicated to identifying current problems of legislative regulation of priority innovation areas in Ukraine and developing proposals for their solution. Basing on a systematic analysis of the provisions of the laws of Ukraine "About priority innovation areas in Ukraine", "About priority areas of science and technology", "About state purpose-oriented programs", as well as other legislative acts in chronological perspective, the author has highlighted multiple problems that concern both the content of legislative norms and their proper implementation in the field of legal regulation of innovation planning in Ukraine. As topical problems of legislative regulation of priority innovation areas in the paper are identified: complicated and overloaded mechanism of legislative forming procedure of strategic and medium-term innovation areas; violation of the procedure and deadlines for the formation of priority innovation areas in Ukraine for the period after 2021; improper compliance with the requirements of the law by the ministries responsible for this area; inconsistency of the content of the Procedure for formation, examination and discussion of priority innovation areas with the provisions of the Law of Ukraine "About priority innovation areas in Ukraine"; the absence of the current Methodology of examination the strategic priority innovation areas and mediumterm priority innovation areas at the national level. The article summarizes that the absence of the current Methodology of examination and outdated procedure for the formation of these areas actualize the risks of identifying inappropriate strategic priority innovation areas, far from current global innovation trends. As actual directions of overcoming the identified problems the author offers revision of the legal mechanism of forming the priority innovation areas towards simplification of consideration and coordination procedures; bringing in line with the content of legislative acts regulating the formation of priority innovation areas; development of the relevant state purpose-oriented program.

Key words: planning of innovation activity, national innovation system, innovation development, public authority, expertise, legal regulation, the state purpose-oriented program. 